\title{
Impact of Fertilizers on the Seed Quality of Aromatic Rice
}

\author{
M. F. Hossain ${ }^{1}$ \\ ${ }^{1}$ School of Agriculture and Rural Development, Bangladesh Open University, Gazipur, Bangladesh \\ Correspondence: M. F. Hossain, School of Agriculture and Rural Development, Bangladesh Open University, \\ Gazipur-1705, Bangladesh. E-mail: faridhossain04@yahoo.com
}

$\begin{array}{ll}\text { Received: November 19, } 2013 & \text { Accepted: December 11, } 2013 \quad \text { Online Published: May 15, } 2014 \\ \text { doi:10.5539/jas.v6n6p35 } & \text { URL: http://dx.doi.org/10.5539/jas.v6n6p35 }\end{array}$

\begin{abstract}
This experiment was conducted in field and laboratory to evaluate the effect of fertilizer application doses in mother plant plots on seed viability, germination and vigor (seedling length) of aromatic rice. The aromatic rice varieties Kataribhog, Badshabhog and BRRI dhan37 were grown with five fertilizer treatments viz., control (no fertilizer), recommended NPKSZn chemical fertilizers, cow dung $5 \mathrm{t} /$ ha, green manure (Sesbania rostrata) 10 $\mathrm{t} / \mathrm{ha}$ and recommended NPKSZn chemical fertilizers with green manure (Sesbania rostrata) $5 \mathrm{t} / \mathrm{ha}$. Seed quality parameters viability, germination and vigor were determined after six months of storage period. Results from tests in the laboratory showed that viability, germination, vigor of aromatic rice seeds were affected by applications of different fertilizer doses in mother plant field, variety and interaction of variety \& fertilizer. All the fertilizer treatments except recommended NPKSZn chemical fertilizer dose kept an acceptable level of germination percentage $(>80 \%)$ but without fertilizer treatment shows better performance in respect of viability, germination and seedling length. Local aromatic rice varieties Kataribhog and Badshabhog performed better than modern aromatic rice variety BRRI dhan 37 .
\end{abstract}

Keywords: aromatic rice, fertilizer, germination, seedling length, viability, vigor

\section{Introduction}

The quality and quantity of seed depend upon different factors include soil, climate and performance of agricultural operations during the growth of the mother plant from planting to harvest (McDonald \& Copeland, 1997). Healthy seeds mean healthy seedlings that finally lead to better production. Seed is the most important input in any crop production and without healthy and quality seeds; all expenditure incurred on other inputs is wasted. Good quality of seed is also one of the important means to increase productivity in any crop (Lamo et al., 2012). Seed vigor and germination ability directly affect yield and seed quality also affect seedling emergence (Tekrony \& Egli, 1991). Seeds are composed of many different types of biochemical's like all living organisms, but seeds are unique because they are a storehouse of compounds that are used as food reserves for the next generation plant (Ferguson \& Mchughlin, 2009). Low carbohydrates, lipids, proteins and phytic acids of seed may be more susceptible to diseases and low germination and vigor of seed (Raboy et al., 1997). The germination, viability and vigor are considered as the most important quality characteristics of the seed. The application of fertilizers is one of the primary methods for improving the availability of soil nutrients to plants. Fertilizing can change rates of plant growth, maturity time, size of plant parts, phytochemical content of plants and seed capabilities (Mevi-Schütz et al., 2003). High-input practices such as heavy use of chemical fertilizers have created a variety of economic, environmental, ecological and social problems. Furthermore, the increasing costs of chemical inputs have left farmers helpless, resulting to decreasing seed quality of certain crops and resulting in the fall of commodity prices and consequently reducing farm income (Tung \& Fernandez, 2007; Khadem et al., 2010). In such situation the organic fertilizer play a major role in order to achieve sustainable agriculture. The germination, viability and vigor are considered as the most important quality characteristics of the seed and obtaining of appropriate values is the main aim of successful program of seed production. Rapid and uniform field emergence is essential to achieve high yield with good quality and quantity in annual crops (Yari et al., 2010). Germination and seedling vigor are the main factors for plant establishment and making optimum plant density and plant production. Several factors like; genetic constitution, environment and nutrition of mother plant, maturity at harvest, seed weight and size, mechanical integrity, deterioration, ageing and pathogens are known to influence seed vigor (Perry, 1980). 
Moreover, some reports also are remarkable that application of 0-200-400-600 kg/ha nitrogen fertilizer has no effect on seed vigor and germination percentage (Osechas et al., 2002). Seed moisture of mungbean was significantly affected by seed lot and fertilizer sources. Seed yield and seed qualities (in terms of germination, vigor and moisture content) were better under organic compared to inorganic fertilizer application. Organic fertilizers are effective fertilizer sources to obtain high mungbean seed yield and seed quality (Aquino \& Fernandez, 2001). Germination percentage of isabgol (Plantago ovate) were higher under organic fertilizer (Raissi et al., 2012). The present research was carried out in order to evaluate the impact of fertilizers application on the seed quality of aromatic rice.

\section{Materials and Methods}

The field experiment was conducted at the Hajee Mohammad Danesh Science and Technology University Farm, Dinajpur, Bangladesh during July to November of 2009. The experimental site was a medium high land belonging to the non-calcareous dark gray floodplain soil under the agro-ecological zone (AEZ-1) of Old Himalayan Piedmont Plain (UNDP \& FAO, 1988). The soil samples of the experimental site were analyses in the Soil Resource Development Institute (SRDI), Dinajpur, Bangladesh. Field with sandy loam soil having a pH value of 6.0.The soil was rich in $\mathrm{P}, \mathrm{S}, \mathrm{Mn}, \mathrm{Fe}, \mathrm{Cu}$ and other nutrients were some extent lower compared to the critical level (Table 1).

Table 1. Soil properties of the experimental site

\begin{tabular}{lll}
\hline Soil Properties & Values & Critical limit \\
\hline $\mathrm{pH}$ & 6.0 & - \\
Organic matter (\%) & 1.62 & - \\
Total N (\%) & 0.09 & 0.12 \\
Available P (ppm) & 25.42 & 7.00 \\
Exchangeable K (me/100g) & 0.23 & 0.20 \\
Available S (ppm) & 13.82 & 10.00 \\
Available $\mathrm{Zn} \mathrm{(ppm)}$ & 0.77 & 0.60 \\
Available Ca (me/100g soil) & 2.12 & 2.00 \\
Available $\mathrm{Mg}(\mathrm{me} / 100 \mathrm{~g}$ soil & 0.37 & 0.50 \\
Available $\mathrm{Mn}(\mathrm{ppm})$ & 3.70 & 1.00 \\
Available B (ppm) & 0.25 & 0.20 \\
Available Cu (ppm) & 1.68 & 0.20 \\
Available Fe (ppm) & 59.30 & 4.00 \\
\hline
\end{tabular}

The experiment was laid out in a randomized complete block design with three replications. The experiment consisted of five fertilizer treatments viz., T1 $=$ Control (No fertilizer), T2 $=$ Recommended NPKSZn chemical fertilizer dose (Urea $=150 \mathrm{~kg} / \mathrm{ha}$, Triple super phosphate $(T S P)=60 \mathrm{~kg} / \mathrm{ha}$, Murate of potash $(\mathrm{MOP})=120 \mathrm{~kg} / \mathrm{ha}$, Gypsum $=90 \mathrm{~kg} / \mathrm{ha}$ and Zinc sulphate $\left(\mathrm{ZnSO}_{4}\right)=2.5 \mathrm{~kg} / \mathrm{ha}, \mathrm{T} 3=$ Cow dung $5 \mathrm{t} / \mathrm{ha}, \mathrm{T} 4=$ Green manure $($ Sesbania rostrata) 10 t/ha and T5 = Recommended NPKSZn chemical fertilizer dose with green manure (Sesbania rostrata) $5 \mathrm{t} / \mathrm{ha}$. Three aromatic rice varieties viz. Kataribhog, Badshabhog and BRRI dhan37 were used. The unit plot size was $4.0 \mathrm{~m} \times 2.5 \mathrm{~m} . \mathrm{P}, \mathrm{K}, \mathrm{S}$ and $\mathrm{Zn}$ fertilizer were applied as basal at final land preparation. Well-decomposed sundry cow-dung $=5 \mathrm{t} / \mathrm{ha}$ was mixed in the defined specific plots at the time of final land preparation. Nitrogen was applied in the form of urea $=150 \mathrm{~kg} / \mathrm{ha}$ in two equal splits at 20 and 45 days after transplanting. Thirty-day-old seedlings were transplanted in the plots at a spacing of $20 \mathrm{~cm} \mathrm{X} 15 \mathrm{~cm}$ using 3 seedlings/hill. All other cultural practices were done uniformly as per recommendation. Individual plots were harvested to obtain seeds. After proper drying, $5 \mathrm{~kg}$ of each variety of seeds were put in airtight plastic containers and kept in laboratory November 2009 to April 2010. The seed quality study was conducted at the Agronomy laboratory of the university. After six months of storage seed samples were tested for viability, germination and vigor (seedling length) using a Completely Randomized Design (CRD) with four replications. Seeds were placed on the moist filter paper in Petri-dishes and germination was calculated following standard 
method (ISTA, 1966). Normal seedlings were counted following the methods of Thomson (1979). All the germinated seeds (normal and abnormal seedlings) were counted for viability test and normal seedlings were counted for germination test. For vigor test, the indirect method 'Seedling length measurement' was followed. Length of radicle and plumule of 10 seedlings (at random) from each samples were measured and recorded which is the indication of seed vigor (Huda, 2001). Data on various parameters were statistically analyzed and Duncan's Multiple Range Test (DMRT) compared the means.

\section{Results and Discussion}

\subsection{Viability}

The effect of fertilizer on viability of seed after six months of storage was found statistically significant. The highest viability $(92.56 \%)$ of aromatic rice seed was found under control plots (T1) and the second highest $(90.56 \%)$ was obtained by Recommended NPKSZn chemical fertilizer with Green manure $5 \mathrm{t} / \mathrm{ha}$ (T5). However, the lowest viability percentage after six-month storage was found under recommended NPKSZn chemical fertilizer dose (T2) that was statistically similar to T3 (well decomposed cow dung $5 \mathrm{t} / \mathrm{ha}$ ) and T4 treatment (Green manure $10 \mathrm{t} / \mathrm{ha}$ ) (Table 2). Seeds of mungbean produced without fertilizer treatment remained viable all throughout the storage period but grown with complete fertilizer were no longer viable, declined below $20 \%$ after only 2 months and were no longer viable after 4 months (Aquino \& Fernandez, 2001). Local aromatic rice cv. Badshabhog performed better in respect of viability percentage (93.20\%) that was statistically similar to Kataribhog. Lowest viability percentage $(78.00 \%)$ was observed in modern aromatic rice variety BRRI dhan 37 (Table 2). The interaction effect of fertilizer and variety on viability was significant. The highest seed viability $(95.00 \%)$ was obtained from Badshabhog under control treatment (T1V2) that was statistically similar to T1V1, T3V1, T3V2, T4V1, T4V2, T5V1 and T5V2 (Table 3).

Table 2. Effect of fertilizer and variety on the seed viability, germination and vigor (seedling length) of aromatic rice

\begin{tabular}{llll}
\hline Treatment & \multicolumn{3}{c}{ Seed quality parameters } \\
\cline { 2 - 4 } Fertilizer dose & Viability (\%) & Germination (\%) & Individual seedling length (cm) \\
\hline T1 & $92.56 \mathrm{a}^{*}$ & $84.89 \mathrm{a}$ & $18.02 \mathrm{a}$ \\
$\mathrm{T} 2$ & $84.50 \mathrm{c}$ & $78.11 \mathrm{c}$ & $16.90 \mathrm{~b}$ \\
T3 & $85.89 \mathrm{c}$ & $81.56 \mathrm{~b}$ & $16.91 \mathrm{~b}$ \\
T4 & $85.67 \mathrm{c}$ & $80.22 \mathrm{~b}$ & $16.76 \mathrm{~b}$ \\
T5 & $90.56 \mathrm{~b}$ & $82.00 \mathrm{~b}$ & $17.86 \mathrm{a}$ \\
Variety & & & \\
V1 & $92.33 \mathrm{a}$ & $83.80 \mathrm{a}$ & $18.94 \mathrm{a}$ \\
V2 & $93.20 \mathrm{a}$ & $85.00 \mathrm{a}$ & $17.39 \mathrm{~b}$ \\
V3 & $78.00 \mathrm{~b}$ & $75.27 \mathrm{~b}$ & $15.53 \mathrm{c}$ \\
\hline
\end{tabular}

*Figures in a column followed by different letters differ significantly but with common letter (s) do not differ significantly at $5 \%$ level of probability.

$\mathrm{T} 1=$ Control (no fertilizer), T2 $=$ Recommended dose of chemical NPKSZn fertilizers doses, T3 $=$ Cow dung 5 $\mathrm{t} / \mathrm{ha}, \mathrm{T} 4=$ Green manure (Sesbania rostrata) $10 \mathrm{t} / \mathrm{ha}$ and T $5=$ Recommended NPKSZn chemical fertilizer dose + Green manure 5 t/ha (Sesbania rostrata); V1= Kataribhog, V2 =Badshabhog and V3 = BRRI dhan37.

\subsection{Germination}

The effect of fertilizer dose on germination after six months of storage was significant (Table 2). Fertilizer treatments except recommended NPKSZn chemical fertilizer dose maintained an acceptable level of germination percentage $(>80 \%)$. The highest germination of seed $(84.89 \%)$ was obtained when seeds produced without fertilizer (T1). The second highest germination percentage $(82.00 \%)$ was obtained by Recommended NPKSZn chemical fertilizer with Green manure 5 t/ha (T5) that was statistically similar to T3 and T4 treatments. The germination percentage was the lowest $(78.11 \%)$ when seeds produced by recommended NPKSZn chemical fertilizer dose (T2). High application of nitrogen fertilizer in pea had decreased yield and germinating ability (Pollock 
\& Ross, 1972). Seed germination of rice did not vary significantly due to methods of cultivation, manures and fertilizers (Krishna et al., 2008). Seeds of mungbean without fertilizer kept an acceptable level of germination percentage after the 6 months storage period and declined only by about 5\% after 2 months (Aquino \& Fernandez, 2001). Maximum germination percentage of isabgol (Plantago ovate) in plots treated with animal manure due to optimum availability of nutrients at all stages and thus gave bold, good quality and vigorous seeds (Raissi et al., 2012). However, in case of seed germination, local and modern aromatic rice varieties respond differently. Local small aromatic rice cv. Badshabhog showed higher germination percentage $(85.00 \%)$ that was statistically similar to Kataribhog. Lowest germination percentage (75.27\%) was observed in modern aromatic rice variety BRRI dhan37 (Table 2). The varietal differences in germination of the seeds also reported by Sa et al. (1988). The germination rate of small seed was the highest among other seed sizes. Large seed needs more water than small seed and resulted in decrement of germination rate (Sadeghi et al., 2011). The interaction of fertilizer and variety on germination percentage was significant. The highest seed germination percentage $(87.67 \%)$ was obtained from Badshabhog under control treatment (T1V2) that was statistically similar to T1V1, T3V1, T3V2, T5V1 and T5V2 (Table 3).

Table 3. Combined effect of fertilizer and variety on the seed viability, germination and vigor (seedling length) of aromatic rice

\begin{tabular}{llll}
\hline \multirow{2}{*}{ Treatment } & \multicolumn{3}{c}{ Seed quality parameters } \\
\cline { 2 - 4 } & Viability $(\%)$ & Germination $(\%)$ & Individual seedling length $(\mathrm{cm})$ \\
\hline T1 V1 & $94.67 \mathrm{a}^{*}$ & $86.33 \mathrm{ab}$ & $18.99 \mathrm{a}-\mathrm{c}$ \\
T1 V2 & $95.00 \mathrm{a}$ & $87.67 \mathrm{a}$ & $17.53 \mathrm{~d}-\mathrm{f}$ \\
T1 V3 & $88.00 \mathrm{~d}$ & $80.67 \mathrm{~d}$ & $17.53 \mathrm{~d}-\mathrm{f}$ \\
T2 V1 & $89.67 \mathrm{~cd}$ & $80.67 \mathrm{~d}$ & $18.57 \mathrm{a}-\mathrm{d}$ \\
T2 V2 & $91.00 \mathrm{bd}$ & $82.00 \mathrm{~cd}$ & $17.26 \mathrm{~d}-\mathrm{f}$ \\
T2 V3 & $73.00 \mathrm{f}$ & $71.67 \mathrm{f}$ & $14.87 \mathrm{~g}$ \\
T3 V1 & $91.67 \mathrm{a}-\mathrm{c}$ & $84.00 \mathrm{a}-\mathrm{d}$ & $19.61 \mathrm{a}$ \\
T3 V2 & $92.33 \mathrm{a}-\mathrm{c}$ & $85.33 \mathrm{a}-\mathrm{c}$ & $16.66 \mathrm{ef}$ \\
T3 V3 & $73.67 \mathrm{f}$ & $75.33 \mathrm{e}$ & $14.47 \mathrm{~g}$ \\
T4 V1 & $92.00 \mathrm{a}-\mathrm{c}$ & $83.73 \mathrm{~b}-\mathrm{d}$ & $18.22 \mathrm{~b}-\mathrm{d}$ \\
T4 V2 & $93.00 \mathrm{a}-\mathrm{c}$ & $83.67 \mathrm{~b}-\mathrm{d}$ & $19.17 \mathrm{a}-\mathrm{c}$ \\
T4 V3 & $72.00 \mathrm{f}$ & $73.67 \mathrm{e}-\mathrm{f}$ & $12.87 \mathrm{~h}$ \\
T5 V1 & $93.67 \mathrm{ab}$ & $84.67 \mathrm{a}-\mathrm{c}$ & $19.72 \mathrm{ab}$ \\
T5 V2 & $94.67 \mathrm{a}$ & $86.73 \mathrm{ab}$ & $16.34 \mathrm{f}$ \\
T5 V3 & $83.33 \mathrm{e}$ & $75.00 \mathrm{ef}$ & $17.92 \mathrm{ef}$ \\
\hline
\end{tabular}

*Figures in a column followed by different letters differ significantly but with common letter ( $\mathrm{s}$ ) do not differ significantly at $5 \%$ level of probability.

$\mathrm{T} 1=$ Control (no fertilizer), T2 $=$ Recommended dose of chemical NPKSZn fertilizers doses, T3 $=$ Cow dung 5 $\mathrm{t} / \mathrm{ha}, \mathrm{T} 4=$ Green manure (Sesbania rostrata) $10 \mathrm{t} / \mathrm{ha}$ and T5 $=$ Recommended NPKSZn chemical fertilizer dose + Green manure $5 \mathrm{t} / \mathrm{ha}$ (Sesbania rostrata); V1=Kataribhog, V2=Badshabhog and V3=BRRI dhan37.

\subsection{Seedling Length}

Seed vigor as expressed in terms of seedling length was significantly affected by different fertilizer treatments in mother plant fields after six months of storage in laboratory condition (Table 2). Maximum seedling length $(18.02 \mathrm{~cm})$ was found in seeds that produced without fertilizers (T1) which was statistically similar to seed produced under recommended NPKSZn chemical fertilizer dose with green manure $5 \mathrm{t} / \mathrm{ha}$ (T5). In mungbean, without fertilizer treatment had higher vigor than when fertilized (Aquino \& Fernandez, 2001). Farm Yard Manure (FYM) and Recommended Dose of Fertilizers (RDF) also enhanced the rice seed vigor index significantly. The better filling of seeds, which indicates the better food reserves in the seeds produced with these 
treatments, might have resulted in better quality parameter (Krishna et al., 2008; Nandisha \& Mahadevappa, 1984; Udaykumar, 2005). In unfertilized seedbeds, seedlings allocate more dry matter to the roots for better nutrient uptake, whereas in soil where nutrients are easily available, shoot growth can take more preference over roots. After the establishment phase, seedling growth rate is a function of soil nutrient status (Mishra \& Salokhe, 2008). Maximum primary stem length of isabgol (Plantago ovate) was observed that produced in plots treated with animal manure (Raissi et al., 2012). Shoot length and dry matter of hybrid sorghum (CSH-5) were increased upon seed treatment with organic fertilizer (V. P. Savalagi \& V. Savalagi, 1991). Primary stem length of seeds in laboratory condition was higher that produced with manure (Barea \& Azcon, 1978). Maximum seedling length $(18.94 \mathrm{~cm})$ was found in local aromatic rice cv. Kataribhog and the minimum seedling length $(15.53 \mathrm{~cm})$ was observed in modern aromatic rice cv. BRRI dhan37 (Table 2). The interaction effect of fertilizer and variety on seedling length was significant. The highest seedling length $(19.61 \mathrm{~cm})$ was obtained from Kataribhog under cow dung 5 t/ha (T3V1) treatment that was statistically similar to T1V1, T2V1, T4V2 and T5V1 (Table 2). Environmental factors particularly soil nutrient status play an important roles in determining the response of crop seeds to fertilizer inputs (Chiezey, 2013).

\section{Conclusions}

Results from tests in the laboratory showed that viability, germination, vigor (seedling length) of aromatic rice seeds were affected by applications of different fertilizer doses in mother plant fields, varieties and interaction of varieties and fertilizer doses. Fertilizer treatments except recommended NPKSZn chemical fertilizer dose maintained an acceptable level of germination percentage ( $>80 \%)$. Seed shows better performance in terms of seed viability, germination and vigor without fertilizer in the mother plant field after six months of storage, most probably due to lower seed moisture content. Seeds of mungbean without fertilizer treatment had only slight increase in moisture content through the 6 months storage period, while those with inorganic fertilizer increased beyond acceptable level on the second month of storage. The lower moisture content of these storage periods may have partly contributed to the maintenance of viability and vigor. Moisture content of seeds from control treatment was maintained at $13 \%$ and this probably remained viable after 6 months of storage. The abrupt increase in moisture content from $11 \%$ before storage to $17 \%$ after 2 months in storage may have contributed to the significant decline germination. Since at $14 \%$ moisture content storage fungi that contribute to faster seed deterioration start to become active (Aquino \& Fernandez, 2001).

\section{Acknowledgements}

The author grateful to the Agronomy Department of Hajee Mohammad Danesh Science and Technology University, Dinajpur and Soil Resource Development Institute (SRDI) Bangladesh for providing the necessary facilities during this study.

\section{References}

Aquino, A. L., \& Fernandez, P. G. (2001). Comparative productivity \& seed quality of mungbean grown under organic \& conventional production systems. Philippine Journal of. Crop Sciences, 26(3), 45-51.

Barea J. M., \& Azcon, A. C. (1978). Effects of plant hormones present in bacterial cultures on the formation and responses to VA endomycorrhizae. New Phytol, 80, 359-364.

Chiezey, U. F. (2013). Field Performance of Soybean (Glycine max (L.) Merill) with Farmyard Manure and Inorganic P Fertilizers in the Sub-Humid Savanna of Nigeria. Journal of Agricultural Science, 5(10), 46-55. http://dx.doi.org/10.5539/jas.v5n10p46

Ferguson J. M., \& Mchughlin, F. W. (2009). Seed and seed quality (pp. 25-66). North Carolina Department of Agriculture Seed Program.

Huda, M. N. (2001). Quality status. Why Quality Seed? Reality and Vision (pp. 106-108). Published by Bangladesh -German Seed Development Project.

ISTA (1966). International Rules for Seed Testing. Intl. Seed Testing Assoc. Proc., 72, 1-52.

Khadem S. A., Galavi, M., Ramrodi, M., Mousavi, S. R., Rousta, M. J., \& Rezvani, M. P. (2010). Effect of animal manure and superabsorbent polymer on corn leaf relative water content, cell membrane stability and leaf chlorophyll content under dry condition. Australian Journal of Crop Sciences, 4, 642-647.

Krishna, A., Biradarpatil, N. K., \& Channappagoudar, B. B. (2008). Influence of system of rice intensification (sri) cultivation on seed yield and quality. Karnataka Journal of Agriculture Sciences, 21(3), 369-372.

Lamo K. B., Korla, N., \& Ahukla, Y. R. (2012). Effect of different organic and inorganic nutrient sources on seed production of radish (Raphanus sativus cv. chinese pink). Leaf sciences leaflets, 2, 38-44. 
McDonald, M. B., \& Copeland. L. O. (1997). Seed Production, Principles seed priming treatments on emergence and seedling growth of Sorghum bicolor and Pennisetum glaucum in pot trials under greenhouse conditions. Journal of Agronomy \& Crop Sciences, 182, 135-41.

Mevi Schütz, T., Goverde, J. M., \& Erhardt, A. (2003). Effects of fertilization and elevated $\mathrm{CO}_{2}$ on larval food and butterfly nectar amino acid preference in Coenonympha pamphilus L. Behavioral Ecology and Sociobiology, 54, 36-43.

Mishra, A., \& Salokhe V. M. (2008). Seedling Characteristics and the Early Growth of Transplanted Rice under Different Water Regimes. Experimental Agriculture, 44, 1-19.

Nandisha, B. S., \& Mahadevappa, M. (1984). Influence of mother plant, nutrition, and spacing in planting value of rice seeds. Seed. Research, 12(2), 52-32.

Osechas, D., Torres, A., \& Becerra, L. (2002). Effect of nitrogen fertilization on the production and quality of seed of signal grass (Urochloadecumbens, Stapf). Zootecnica Tropical, 20(1), 135-143.

Perry, D. A. (1980). The concept of seed vigour and its relevance to seed production techniquea. In P. D. Hebbleth Waite (Ed.), Seed production (pp. 585-597). Butterworth, London.

Pollock, B. M., \& Ross, E. (1972). Seed and seedling vigour. In T. T. Kozlowski (Ed), Seed biology. Academic Press.

Raboy, V., Young, K. A., \& Ertl, D. S. (1997). Breeding corn for improved nutritional value and reduced environmental impact. In R. J. Falasca (Ed.), Proc. of Fifty-Second Annu. Corn and Sorghum Indus. Res. Conf. (pp. 271-282). Chicago. 10-11 Dec. Am. Seed Trade Assoc.Washington, D.C.

Raissi, A., Galavi, M., Ramroudi, M., Mousavi, S. R., \& Rasoulizadeh, M. N. (2012). Effects of phosphate bio-fertilizer, organic manure and chemical fertilizers on yield, yield components and seed capabilities of isabgol (Plantago ovate). Interational Journal Agriculture \& Crop Sciences, 4(24), 1821-1826.

Sa, J. G., Kim, K. S., Hun, B., \& Kim, K. H. (1988). Effect of plant growth regulator treatments during the grain filling period on seed and viviparous germination in rice. Korean Journa lof Crop Sciences, 33(3), 262-269.

Sadeghi, H., Khazaei, F., Sheidaei, S., \& Yari, L. (2011). Effect of Seed Size on Seed Germination Behavior of Safflower (Carthamus tinctorius L.). ARPN Journal of Agriculture \& Biological Sciences, 6(4), 5-8.

Savalagi, V. P., \& Savalagi, V. (1991). Effect of Azospirillum brasilense and earthworm cast on seed treatment in sorghum. Journal of Maharashtra Agricultural Universities, 16, 107-108.

Tekrony, D. M., \& Egli, D. B. (1991). Relationship of seed vigour to crop yields a review. Crop Science, 31, 816-822.

Thomson, J. R. (1979). An Introduction to Seed Technology (pp. 1-87). East Kilbride, Scotland: Thomson Litho Ltd.

Tung, L. D., \& Fernandez, P. G. (2007). Yield and seed quality of modern and traditional soybean (glycine max) under organic, biodynamic and chemical production practices in the Mekong delta of Vietnam. Omonrice, $15,75-85$.

Udyakumar. (2005). Studies on System of Rice Intensification (SRI) for seed yield and seed quality. M.Sc. (Agrculture) Thesis. Acharya N.G. Ranga Agriculture University., Hyderabad, India.

UNDP \& FAO. (1988). Land Resources Appraisal of Bangladesh for Agricultural Development. Report 2 (pp. 117-130). Agro ecological Regions of Bangladesh. United Nations Development Programme and Food and Agriculture Organization of the United Nations.

Yari, L., Aghaalikhani, M., \& Khazaei, F. (2010). Effect of Seed priming duration and temperature on seed germination behavior of bread wheat (Triticum aestivum L.). ARPN Journal of Agriculture \& Biological Sciences, 5(1).

\section{Copyrights}

Copyright for this article is retained by the author(s), with first publication rights granted to the journal.

This is an open-access article distributed under the terms and conditions of the Creative Commons Attribution license (http://creativecommons.org/licenses/by/3.0/). 